\title{
VLDL Induced Modulation of Nitric Oxide Signalling and Cell Redox Homeostasis in HUVEC
}

\author{
Maria Chiara Magnifico, ${ }^{1}$ Roxana Elena Oberkersch, ${ }^{2}$ Azzurra Mollo, ${ }^{1}$ Luca Giambelli, ${ }^{3}$ \\ Yasmine Grooten, ${ }^{4}$ Paolo Sarti, ${ }^{1}$ Graciela Cristina Calabrese, ${ }^{2}$ and Marzia Arese ${ }^{1}$ \\ ${ }^{1}$ Department of Biochemical Sciences, Sapienza University of Rome, Rome, Italy \\ ${ }^{2}$ Universidad de Buenos Aires, Facultad de Farmacia y Bioquímica, Departamento de Ciencias Biológicas, Cátedra de Biología \\ Celular y Molecular, Buenos Aires, Argentina \\ ${ }^{3}$ Blood Transfusion Service and Hematology, Umberto I Hospital, Rome, Italy \\ ${ }^{4}$ Department of Analytical Chemistry, Applied Chemometrics and Molecular Modelling, Vrije Universiteit Brussel, \\ Brussels, Belgium
}

Correspondence should be addressed to Graciela Cristina Calabrese; gcalabe@ffyb.uba.ar and Marzia Arese; marzia.arese@uniroma1.it

Received 21 April 2017; Revised 31 July 2017; Accepted 15 August 2017; Published 20 September 2017

Academic Editor: Vicenta L. Cortes

Copyright (c) 2017 Maria Chiara Magnifico et al. This is an open access article distributed under the Creative Commons Attribution License, which permits unrestricted use, distribution, and reproduction in any medium, provided the original work is properly cited.

High levels of circulating lipoprotein constitute a risk factor for cardiovascular diseases, and in this context, the specific role of the very-low-density lipoproteins (VLDL) is poorly understood. The response of human umbilical vein endothelial cells (HUVEC) to VLDL exposure was studied, especially focusing on the pathways involved in alteration of redox homeostasis and nitric oxide (NO) bioavailability. The results obtained by the analysis of the expression level of genes implicated in the NO metabolism and oxidative stress response indicated a strong activation of inducible NO synthase (iNOS) upon $24 \mathrm{~h}$ exposure to VLDL, particularly if these have been preventively oxidised. Simultaneously, both mRNA and protein expression of endothelial NO synthase (eNOS) were decreased and its phosphorylation pattern, at the key residues Tyr495 and Ser1177, strongly suggested the occurrence of the eNOS uncoupling. The results are consistent with the observed increased production of nitrites and nitrates (NOx), reactive oxygen species (ROS), 3-nitrotyrosine (3-NT), and, at mitochondrial level, a deficit in mitochondrial $\mathrm{O}_{2}$ consumption. Altogether, these data suggest that the VLDL, particularly if oxidised, when allowed to persist in contact with endothelial cells, strongly alter NO bioavailability, affecting redox homeostasis and mitochondrial function.

\section{Introduction}

Atherosclerosis, one of the principal causes of morbidity and mortality in occidental countries, is a disease affecting large and medium-sized muscular arteries, characterised by endothelial dysfunction and vascular inflammation [1-3]. Dyslipidaemia, and in particular, the increased concentration of cholesterol esters and low-density lipoproteins (LDL) at the arterial intima surface, has long been recognised as a major proatherogenic factor [4] potentially more dangerous for the vessels upon increasing the lipid oxidation level [5-8]. Not only the LDL but also the very-low-density lipoproteins
(VLDL), the physiological precursors of the LDL, might share the responsibility of the onset and builds up of the atherosclerotic plaques [9]. The implication in the atherosclerotic lesion of VLDL can be indirect, since the more elevated the VLDL concentration, the higher the LDL accumulation, but also direct due to the straight molecular interactions with the arterial cell components, membranes, and receptors $[10,11]$.

Evidence has been collected suggesting that, as reported for the LDL [5], also the oxidation of VLDL triggers a cascade of proatherogenic and proinflammatory cell responses [12]. These include lipoprotein retention in the arterial wall and 
recruitment of macrophages at the vessel level; under these conditions, foam cells are formed and eventually the atherosclerotic plaque builds up $[13,14]$.

Interestingly, while the role of LDL and their redox state in the atherogenesis have been both intensively studied [15-18], the experimental evidence supporting the direct involvement of VLDL, native or oxidized, in the onset and development of atherosclerosis is still limited.

Previous reports have shown an increased production of reactive oxygen species (ROS) by mitochondria, accumulation of mitochondrial DNA damage, and progressive respiratory chain dysfunction associated with atherosclerosis [19-23]. A growing body of evidence suggests that alterations of the nitric oxide (NO) synthesis may be involved with this disease $[18,24,25]$.

As a gaseous cell messenger, NO regulates several pathways both in prokaryotes and in eukaryotes [18, 26-29], including the modulation of cell energetic through the interaction with electron transport chain proteins [30-32]. Very relevant to cardiovascular diseases, the NO generated by endothelial cells plays a crucial role in the blood pressure control via relaxation of the vessel muscular smooth muscle cells [33].

Studies on knockout mice demonstrated that NO produced at low (nM) concentration by the constitutive NO synthases (eNOS and nNOS) exerts vasculo-protective effects, whereas higher NO concentration levels $(\mu \mathrm{M})$, as those synthesized by the inducible NOS (iNOS), are more often associated with oxi/nitrosative stress of vessels and tissues $[34,35]$.

Moreover, it has been observed that under condition favoring oxidative stress and inflammation, the impairment of the physiological activity of the eNOS may occur, leading to the so called "uncoupling state" characterized by the production of superoxide $\mathrm{O}_{2}^{-\bullet}$ instead of $\mathrm{NO}$ [36-38].

The present work was aimed at characterising the response of vascular endothelial cells in culture to a timepersistent $(24 \mathrm{~h})$ administration of VLDL as purified from human blood sera (native), or oxidised, focusing on the NO metabolism, the ROS production, and the changes of the primary mitochondrial function [39]. Human umbilical vein endothelial cells (HUVEC) have been taken as a model of vascular endothelium, and within the simplification of a monoculture, it allowed a detailed biochemical characterisation of eNOS biosynthesis and function, pointing to a key role played by this enzyme in the early redox unbalance associated to the onset of atherosclerosis.

\section{Materials and Methods}

2.1. Cell Culture. Human umbilical vein endothelial cells (HUVEC, ATCC CRL-1730) were cultured on $0.2 \%(w / v)$ gelatin-precoated flasks or multiwell plates (Falcon, BD Biosciences, USA) and grown at $37^{\circ} \mathrm{C}, 5 \% \mathrm{CO}_{2}, 95 \%$ air in F-12K medium containing $1.26 \mathrm{~g} / \mathrm{L}$ glucose, $0.1 \mathrm{mg} / \mathrm{mL}$ heparin, $0.03 \mathrm{mg} / \mathrm{mL}$ endothelial cell growth supplement (ECGS), 10\% fetal bovine serum (FBS), $100 \mathrm{U} / \mathrm{mL}$ penicillin, $100 \mu \mathrm{g} / \mathrm{mL}$ streptomycin, and $1.5 \mathrm{~g} / \mathrm{L}$ sodium bicarbonate.
The day before the experiments, cells were depleted of serum for $4 \mathrm{~h}$ and thereafter incubated in serum-free medium for $24 \mathrm{~h}$ with native VLDL (n-VLDL) or oxidised VLDL (ox-VLDL), at the concentration of 75 or $140 \mu \mathrm{g}$ protein $\mathrm{mL}^{-1}$, the former assayed only in a subset of experiments.

Controls were carried out in the absence of VLDL, under otherwise identical conditions. When necessary, HUVEC were harvested by trypsinization and centrifugation $(900 \times \mathrm{g})$ and carefully suspended in the working medium, at suitable density (see text). None of the treatments affected cellular viability of HUVEC, as determined by cell counts, morphology, and trypan blue exclusion analysis.

Cell lysis was performed by CelLytic ${ }^{\mathrm{TM}}$ MT Cell Lysis Reagent (Sigma-Aldrich, USA) in the presence of the Protease Inhibitor Cocktail (Sigma-Aldrich, USA); protein content was determined according to bicinchoninic acid (BCA) assay (Sigma-Aldrich, USA), and citrate synthase activity, considered as representative of the mitochondrial mass, was measured as described [40].

2.2. VLDL Isolation and Ethics Statement. n-VLDL (density: $0.95-1.006 \mathrm{~kg} / \mathrm{L}$ ) were isolated from human sera by preparative ultracentrifugation following the procedure described by Redgrave et al. [41]. Serum samples were collected from typically 40-50 healthy volunteers of age comprised between 20 and 40 years (gender equally represented) after $12 \mathrm{~h}$ fasting, in order to minimize the biological variability among the preparations. The presence of chylomicrons in fresh sera was eliminated centrifuging for $30 \mathrm{~min}$ at $15,000 \mathrm{rpm}$. Then, $\mathrm{n}$-VLDL were obtained by ultracentrifugation at $105,000 \times \mathrm{g}$, for $18 \mathrm{~h}$ at $15^{\circ} \mathrm{C}$ in a $1.006 \mathrm{~kg} / \mathrm{L}$ density solution. After ultracentrifugation, the supernatant from the top of each tube was carefully aspirated and pooled. n-VLDL were dialysed against $0.25 \mathrm{mM}$ ethylenediaminetetraacetic acid (EDTA) in phosphate-buffered saline (PBS), using a membrane (molecular weight cut-off: $6-8 \mathrm{kDa}$ ) at $4^{\circ} \mathrm{C}$ overnight. All VLDL preparations were filtered through a sterile $0.45 \mu \mathrm{m}$ filter and, after the evaluation of protein concentration by the BCA $(\sim 500 \mu \mathrm{g} / \mathrm{mL})$, were stored at $-70^{\circ} \mathrm{C}$ until used. The purity of isolated VLDL was checked on agarose gel and sodium dodecyl sulphate polyacrylamide gel electrophoresis (SDS-PAGE), staining with a lipid-specific dye (Sudan Black B) and a protein-specific dye (Coomassie Blue $\mathrm{R}$ 250), respectively.

n-VLDL with high degree of purity were obtained as outcome by its apolipoprotein composition determined by SDSPAGE (Supplementary Figure 1(a) available online at https:// doi.org/10.1155/2017/2697364) and characteristic mobility (Supplementary Figure 1(b)) [42, 43]. Human sera were collected anonymously by the Immunohematology Laboratory, Policlinico Umberto I, Sapienza Università di Roma. The procedure described has been approved by the Ethics Committee of Sapienza University (Prot. number 3610-2015).

2.3. VLDL Oxidation. VLDL oxidation was carried out according to Guha and Gursky [44] using $\mathrm{Cu}^{2+}$ ions $\left(\mathrm{CuSO}_{4}\right)$. Briefly, a solution of purified $\mathrm{n}-\mathrm{VLDL}$, at the concentration $0.2-0.4 \mathrm{mg} \mathrm{mL}^{-1}$ in EDTA-free PBS, was incubated with $\mathrm{CuSO}_{4}, 40 \mu \mathrm{M}$ for $6 \mathrm{~h}$; the reaction was then stopped using 
$1 \mathrm{mM}$ EDTA. Conjugated dienes and thiobarbituric acidreactive substances (TBARS) were quantified in order to monitor lipid peroxidation [45, 46] (Supplementary Figure 1(c) and (d), resp.).

2.4. Real-Time Polymerase Chain Reaction (PCR). After HUVEC incubation, for $24 \mathrm{~h}$, with $\mathrm{n}$-VLDL or ox-VLDL $\left(140 \mu \mathrm{g} \mathrm{mL}^{-1}\right)$, total RNA was extracted using the Nucleo Spin ${ }^{\circledR}$ RNA isolation kit (Macherey-Nagel, Germany), according to the manufacturer's instructions. Total RNA, $1 \mu \mathrm{g}$, was used for the reverse transcription reaction using $\mathrm{RT}^{2}$ First Strand Kit (Qiagen, Germany). The cDNA obtained was hybridised to the Human Nitric Oxide Signalling Pathway $\mathrm{RT}^{2}$ Profiler PCR Array (Qiagen, Germany).

This array contains oligonucleotide primers matching 84 genes whose expression is controlled by or involved in the signalling of NO, superoxide metabolism, and response to oxidative stress (see Table 1). The array includes also genes that are known to be induced or repressed by NO and whose finding therefore can be used as indicator for the activation of NO cell pathways.

2.5. Western Blot. After HUVEC treatments, cells $\left(1 \times 10^{6}\right)$ were lysed with CelLytic MT Reagent (Sigma-Aldrich, USA) in the presence of Protease Inhibitor Cocktail (Sigma-Aldrich, USA). The proteins were separated on $10 \%$ sodium dodecyl sulphate-polyacrylamide gel electrophoresis (SDS-PAGE) and transferred on nitrocellulose membranes (Whatman, GE Healthcare, UK), $1 \mathrm{~h}$ at $100 \mathrm{~mA}$. After $2 \mathrm{~h}$ blocking (PBS with $0.1 \%$ Tween 20 and $3 \%$ BSA), the membranes were incubated overnight at $4^{\circ} \mathrm{C}$ with primary mouse monoclonal antiphospho-Ser1177 and anti-phospho-Thr495 antibodies (BD Transduction Laboratories, USA). Thereafter, the membranes were stripped and reprobed for monoclonal purified mouse anti-eNOS antibodies (BD Transduction Laboratories, USA); $\alpha$-tubulin was used as the reference. The enhanced chemiluminescence (ECL) Horseradish Peroxidase (HRP) anti-mouse secondary antibody (Jackson, Baltimore, PA, USA) was incubated $1 \mathrm{~h}$ at $25^{\circ} \mathrm{C}$, and chemiluminescence was determined (Amersham, GE Healthcare, UK). Densitometric analysis was carried out by the ChemiDoc ${ }^{\mathrm{TM}} \mathrm{MP}$ Image Analysis Software (Bio-Rad, USA).

2.6. ROS Quantification. Cell ROS generation was assessed by using the fluorescent probe $2^{\prime}, 7^{\prime}$-dichlorodihydrofluorescein diacetate (DCFDA, Sigma-Aldrich, USA), with modifications respect to the protocol generally adopted for adherent cells.

Briefly, HUVEC (70-75\% confluent) were incubated with VLDL for $24 \mathrm{~h}$ as already described, then trypsinized, and pelleted at $900 \times \mathrm{g}$ for $5 \mathrm{~min}$ at $20^{\circ} \mathrm{C}$. Cell pellets were resuspended in Hank's buffer at the density $1 \times 10^{5}$ cells $\mathrm{mL}^{-1}$ and plated in 24-well (black) plates.

Immediately after the addition of $10 \mu \mathrm{M}$ DCFDA, the relative fluorescence emission was followed kinetically at $520 \mathrm{~nm}$ for $60 \mathrm{~min}$ (VICTOR ${ }^{\mathrm{TM}}$ Multilabel Counter, PerkinElmer, USA). The value of ROS production is taken at $30 \mathrm{~min}$.

2.7. Nitrate/Nitrite Determination. The accumulation of nitrate/nitrite (NOx) in the culture medium was assessed by using the fluorescent probe 2,3-diaminonaphthalene (DAN) (Fluorometric Assay Kit, Cayman Chemical, USA).

After $24 \mathrm{~h}$ incubation of HUVEC $\left(\sim 2.5 \times 10^{5} \mathrm{cell} / \mathrm{mL}\right)$ with n-VLDL or ox-VLDL, the culture supernatant was centrifuged at $4^{\circ} \mathrm{C}, 1000 \times \mathrm{g}$ for $10 \mathrm{~min}$ and the $\mathrm{NOx}$ content was measured by adding DAN according to the manufacturer's instructions and using a Fluorescence Plate Reader VICTOR Multilabel Counter (PerkinElmer, USA).

2.8. 3-Nitrotyrosine Quantification. The level of 3-nitrotyrosine- (3-NT-) modified proteins was used as marker of protein damage induced in HUVEC by peroxynitrite and quantified using nitrotyrosine ELISA kit (Abcam ab113848, UK).

After treatments with n-VLDL or ox-VLDL at different concentration $(75,140 \mu \mathrm{g} / \mathrm{mL})$, HUVEC were trypsinized, pelleted at $500 \times \mathrm{g}$ for $10 \mathrm{~min}$, and washed twice using PBS buffer. Then, cells $\left(\sim 1 \times 10^{6}\right)$ were suspended in sample extraction buffer and incubated on ice for $20 \mathrm{~min}$. After centrifugation at $12,000 \times \mathrm{g} 4^{\circ} \mathrm{C}$ for $20 \mathrm{~min}$, the $3-\mathrm{NT}$ levels were determined colorimetrically according to the manufacturer's instructions.

2.9. $\mathrm{O}_{2}$ Consumption Measurements. HUVEC incubated with $\mathrm{n}$-VLDL or ox-VLDL $(140 \mu \mathrm{g} / \mathrm{mL})$ were harvested and resuspended in the oxygraph medium consisting of $3 \mathrm{mM}$ $\mathrm{MgCl}_{2} \times 6 \mathrm{H}_{2} \mathrm{O}, 10 \mathrm{mM} \mathrm{KH} \mathrm{PO}_{4}, 20 \mathrm{mM}$ HEPES, $1 \mathrm{~g} / \mathrm{L} \mathrm{BSA}$, $110 \mathrm{mM}$ mannitol, $0.5 \mathrm{mM}$ EGTA, and pH 7.1. Cell density and viability were determined by trypan blue exclusion test. Respiration was assayed as previously described $[47,48]$ using a high-resolution respirometer (Oxygraph-2k; Oroboros Instruments) equipped with two $1.5 \mathrm{~mL}$ chambers with thermostats; data were collected and analysed using the built in software DatLab 4.

Cells $\left(1 \times 10^{6}\right)$ were added to the oxygraph chamber containing the medium, and the system let equilibrate for $5 \mathrm{~min}$. Cell plasma membrane was permeabilised to reducing substrates and effectors with digitonin (see text). The optimal digitonin concentration, $2.7 \mu \mathrm{g} / \mathrm{mL}$, and the incubation time, 10 minutes, were fixed according to [49].

The contribution to cell respiration of any respiratory complex was evaluated according to Kuznetsov et al. with minor modifications [50]. Briefly, $10 \mathrm{~min}$ after the addition of digitonin, $8.8 \mathrm{mM}$ pyruvate and $4.4 \mathrm{mM}$ malate were added and the resting complex I-supported respiration was recorded (state 4); ADP, $2 \mathrm{mM}$, was then added to induce the maximal mitochondrial respiration (state 3), followed by rotenone, $0.5 \mu \mathrm{M}$, to specifically inhibit complex I; succinate, $10 \mathrm{mM}$, was added to induce complex II-supported respiration, and antimycin, $5 \mu \mathrm{M}$, was added to inhibit complex III; finally, complex IV-dependent respiration was activated by $2 \mathrm{mM}$ ascorbate and $0.5 \mathrm{mM} \mathrm{N}, \mathrm{N}, \mathrm{N}^{\prime}, \mathrm{N}^{\prime}$-tetramethyl-pphenylenediamine (TMPD).

2.10. Citrate Synthase. HUVEC were harvested $\left(1 \times 10^{6}\right)$, lysed, and centrifuged at $13,000 \times \mathrm{g}$ for $10 \mathrm{~min}$. Cell lysates were assayed for citrate synthase activity [40] and for total protein content. HUVEC, used as controls or after incubation with n-VLDL or ox-VLDL, displayed the same 


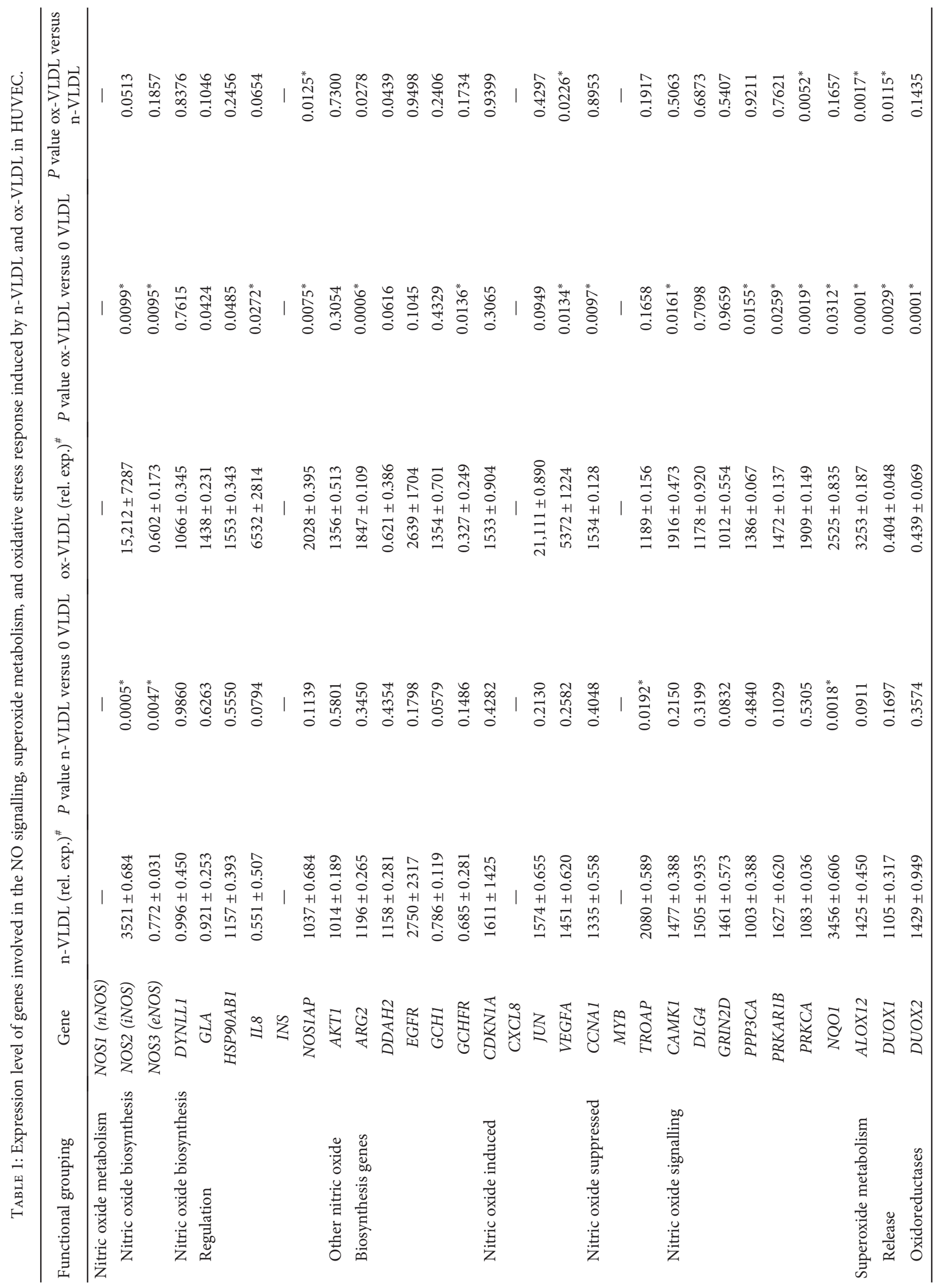




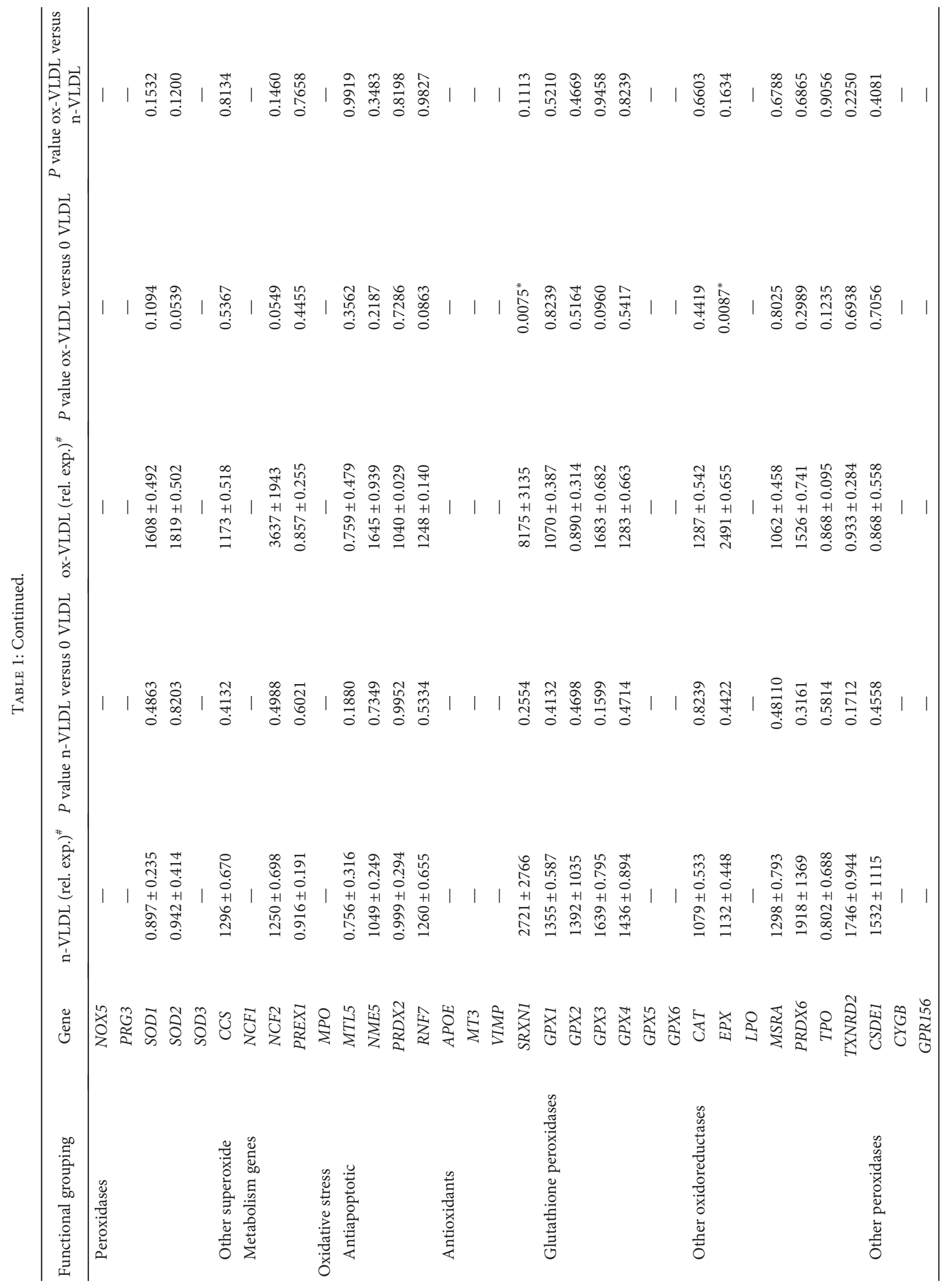




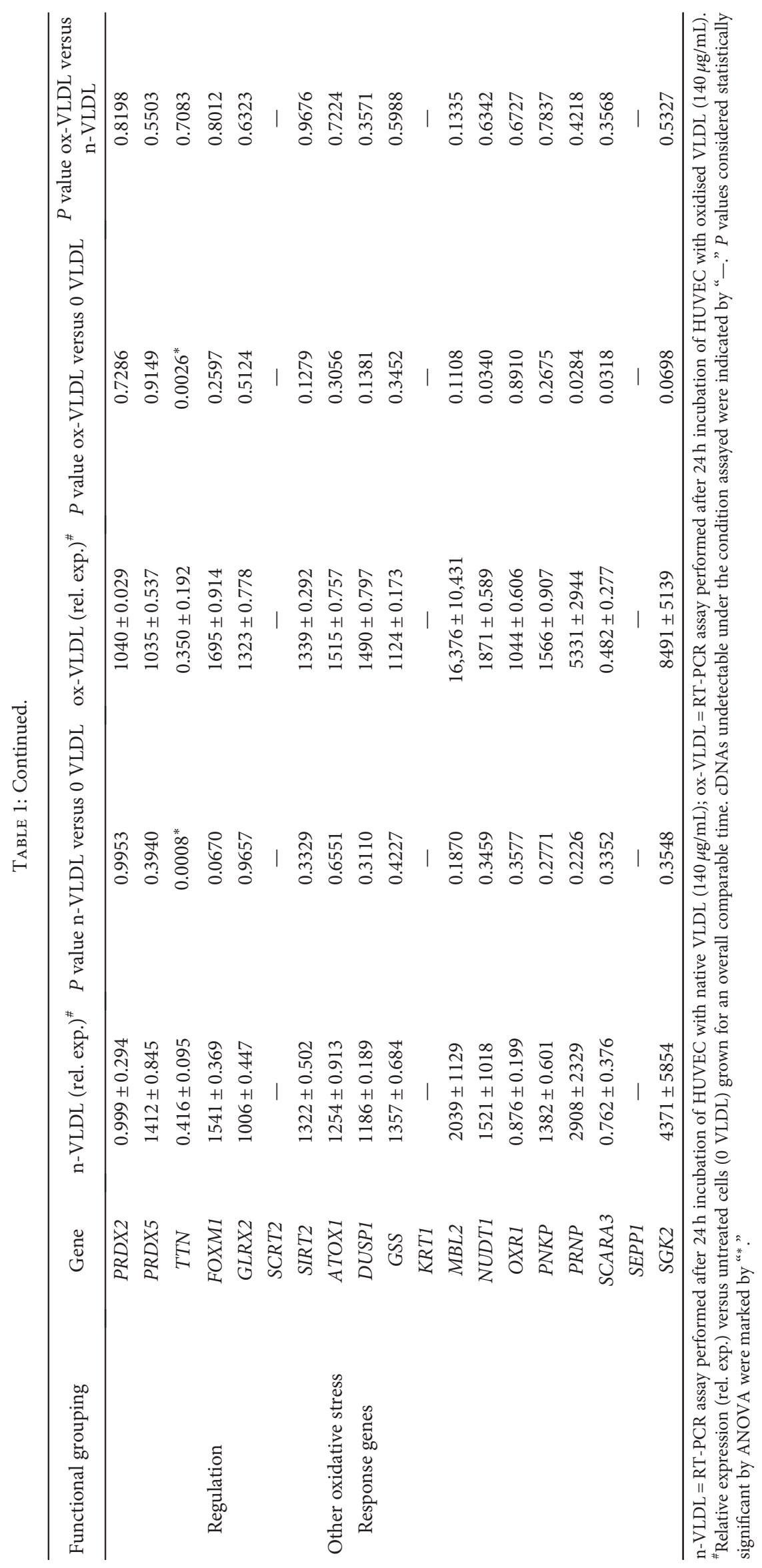




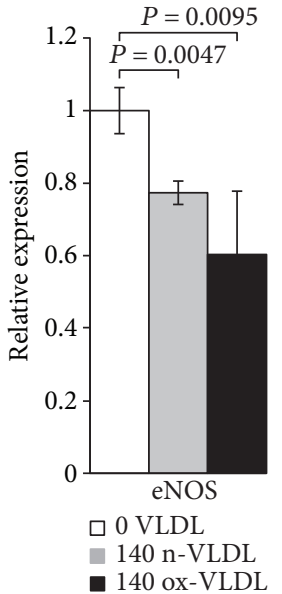

(a)

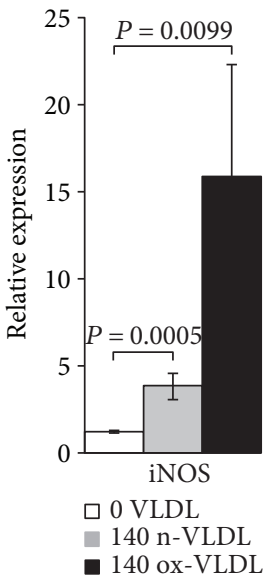

(b)

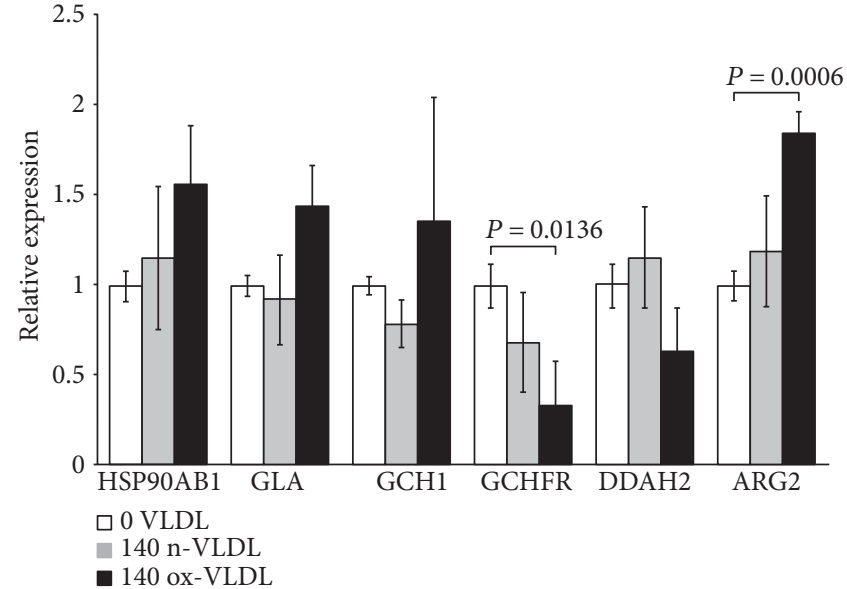

(c)

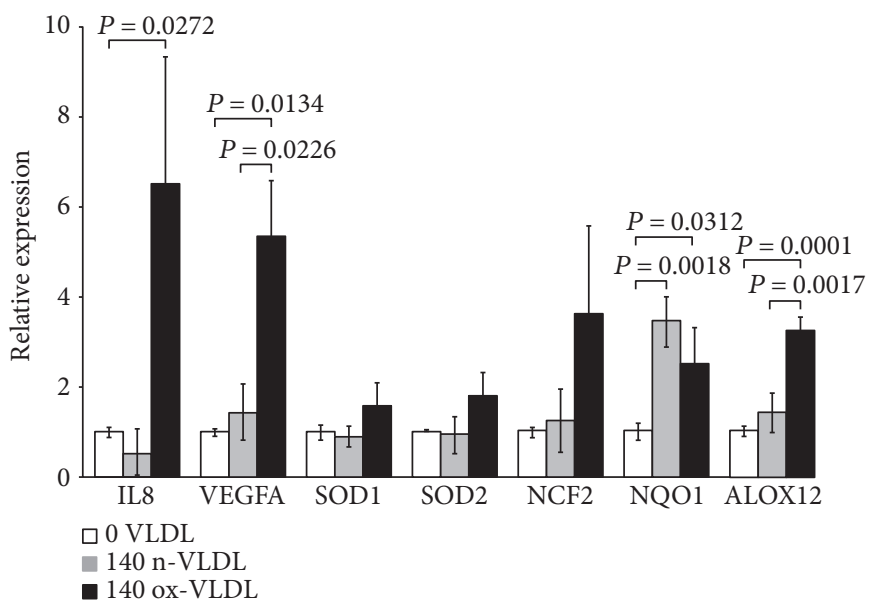

(d)

Figure 1: Gene expression changes induced by VLDL. HUVEC were incubated $24 \mathrm{~h}$ with n-VLDL (grey) or ox-VLDL (black), both $140 \mu \mathrm{g} / \mathrm{mL}$. cDNA were assayed by RT-PCR (Human Nitric Oxide Signalling Pathway RT ${ }^{2}$ Profiler PCR Array). The relative expression of the genes of interest is shown. (a) Endothelial nitric oxide synthase (eNOS). (b) Inducible nitric oxide synthase (iNOS). (c) Genes involved in the regulation of eNOS activity. (i) HSP90AB1: heat shock protein $90 \mathrm{kDa} \alpha$ (cytosolic), class B member 1; (ii) GLA: galactosidase $\alpha$; (iii) GCH1: GTP cyclohydrolase 1; (iv) GCHFR: GTP cyclohydrolase I feedback regulator; (v) DDAH2: dimethylarginine dimethylaminohydrolase 2; (vi) ARG2: arginase, type II. (d) Genes induced by nitric oxide and involved in superoxide metabolism/oxidative stress response. (i) IL8: interleukin 8; (ii) VEGFA: vascular endothelial growth factor A; (iii) SOD1: superoxide dismutase 1, soluble; (iv) SOD2: superoxide dismutase 2, mitochondrial; (v) NCF2: neutrophil cytosolic factor 2; (vi) NQO1: NAD(P)H dehydrogenase, quinone 1; (vii) ALOX12: arachidonate 12-lipoxygenase, $12 \mathrm{~S}$ type. Relative expression calculated after $\beta$-actin normalisation versus control cells. Data $\pm \mathrm{SD} ; n$. of biological experiments $=3$. $P$ values were considered statistically significant by ANOVA.

protein content $(\sim 0.2 \mathrm{mg} / \mathrm{mL})$ and citrate synthase activity $\left(\sim 0.18 \mu \mathrm{mol} / \mathrm{min} / 1 \times 10^{6}\right.$ cells) (not shown).

2.11. Statistical Analysis. Data are the mean \pm standard deviation (SD) of at least three independent biological experiments (as specified in the figure legends), each repeated in three technical replicates. For statistical analysis, one-way analysis of variance (ANOVA), followed by BonferroniHolm post hoc test, was used for multiple comparisons. $P$ values indicated in figures were considered statistically significant by ANOVA. In Table 1 , the $P$ values for all genes are shown; when followed by ${ }^{*}, P$ values were considered significant by ANOVA.

\section{Results}

The transcriptional activity of HUVEC exposed to $140 \mu \mathrm{g} / \mathrm{mL}$ $\mathrm{n}$-VLDL or ox-VLDL was investigated by targeting genes related to NO metabolism and to oxidative stress. The genes included in the screening have been grouped in functional classes (Table 1), and the mRNA production of each gene has been reported as the relative to that of untreated cells (see Materials and Methods).

3.1. eNOS and iNOS Genes. As shown in Figures 1(a) and 1(b) following cell incubation with n-VLDL, the eNOS mRNA expression is slightly downregulated by $\sim 0.25$-fold, whereas the iNOS is upregulated by $\sim 2.5$-fold. When cells 

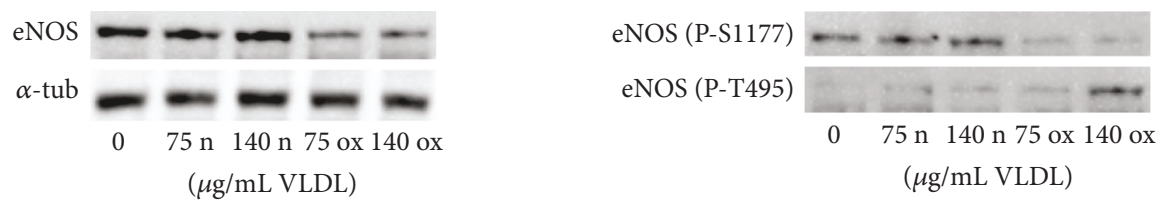

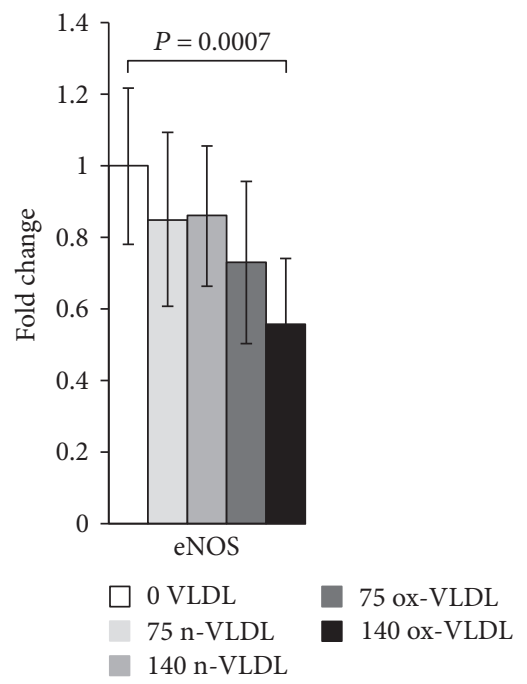

(a)

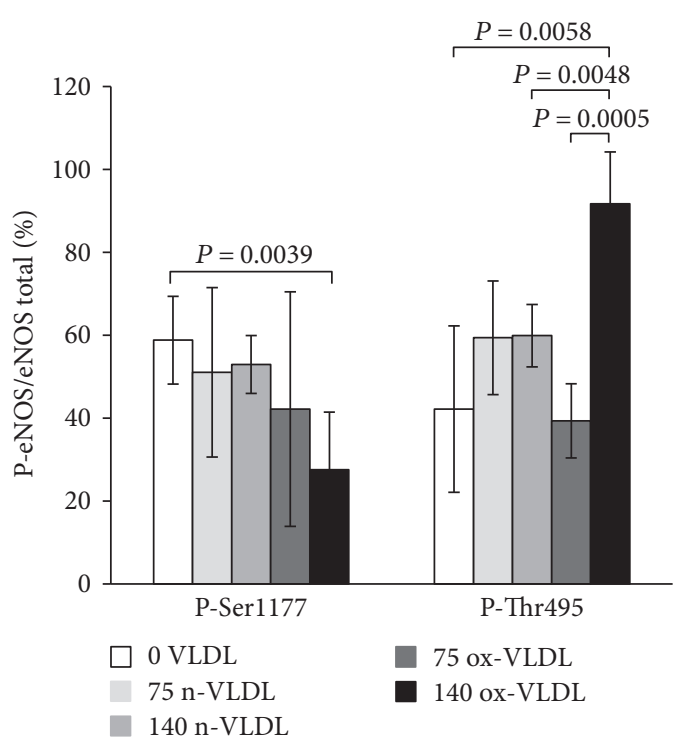

(b)

FIGURE 2: eNOS protein expression and evaluation of uncoupling in response to VLDL by Western blot. HUVEC were incubated $24 \mathrm{~h}$ with (75 and $140 \mu \mathrm{g} / \mathrm{mL}$ ) n-VLDL or ox-VLDL and then assayed by Western blot with anti-eNOS antibodies (see Materials and Methods). (a) Levels of eNOS protein after n-VLDL or ox-VLDL treatment. Densitometric values are shown as fold change versus the eNOS protein expressed by control cells. Data $\pm \mathrm{SD}, n$. of biological experiments $=8$. $P$ values were considered statistically significant by ANOVA. Inset: Western blot pattern of eNOS after $24 \mathrm{~h}$ incubation with $\mathrm{n}$-VLDL or ox-VLDL; $\alpha$-tubulin as reference ( $\alpha$-tub). (b) Phosphorylation of eNOS at Ser-1177 and Thr-495 in response to n-VLDL or ox-VLDL (see Materials and Methods). Data \pm SD, $n$. of biological experiments $=4$. $P$ values were considered statistically significant by ANOVA. Inset: Western blot pattern of eNOS (P-S1177) and eNOS (P-T495) after $24 \mathrm{~h}$ incubation with $\mathrm{n}$-VLDL or ox-VLDL.

were exposed to ox-VLDL, the eNOS mRNA expression was more clearly downregulated $(\sim 0.4$-fold $)$ while the iNOS increased largely by approximately 15 -fold.

3.2. Other NO-Related Genes. This group includes genes involved in the stability and functional regulation of the NOS enzyme. Following cell incubation with ox-VLDL, the HSP90AB1, GLA, GCH1, and ARG2 genes are upregulated, whereas the DDAH2 and the GCHFR genes are downregulated (see Figure 1(c)).

Changes of the expression levels of this selection of genes are very small when induced by $n$-VLDL, varying by a larger extent if VLDL were preliminarily oxidised (see Table 1).

3.3. Inflammation-Related Genes. Along with the iNOS mRNA, also the VEGFA-, IL8-, and ALOX12-encoding genes are upregulated by ox-VLDL, pointing to the activation of inflammation pathways (Figure $1(\mathrm{~d})$ ). The expression of endothelial genes involved in the NADPH oxidase biosynthesis and function, namely, the NCF2 and NQO1, also appears upregulated together with the SOD1 and SOD2 mRNA, the latter increased by $\sim 1.8$-fold (see Table 1 and Figure $1(\mathrm{~d})$ ). In this frame, the $24 \mathrm{~h}$ cell incubation with $\mathrm{n}$-VLDL is clearly less effective.
3.4. eNOS Expression and Uncoupling. The protein expression of eNOS was determined by Western blot analysis in HUVEC incubated with n-VLDL or ox-VLDL. For the analysis, primary antibodies against eNOS, or specifically recognising Thr495- or Ser1177-phosphorylated eNOS, were used. Consistent with the data shown in Figure 1, the exposure to $n$-VLDL leads to a $\sim 20 \%$ decrease of the eNOS protein detected regardless to the lipoprotein concentration used, namely, 75 and $140 \mu \mathrm{gmL}^{-1}$. The exposure to oxVLDL, at the same concentrations, induces, respectively, a $\sim 30 \%$ and $\sim 40 \%$ decrease of protein expression (Figure 2(a)).

The results of Western blot carried out with primary antibodies directed against phosphorylated eNOS indicated differences in phosphorylation at the level of key regulatory sites, Ser1177 and Thr495, upon varying VLDL redox state and concentration. In Figure 2(b), the results were reported as the ratio of phosphorylated eNOS (at Ser1177 or Thr495) over total eNOS (\%). Control cells exhibited a $\sim 60 \%$ phosphorylation at Ser1177 (P-Ser1177), and incubation with $\mathrm{n}$-VLDL (both 75 and $140 \mu \mathrm{g} \mathrm{mL}^{-1}$ ) did not induce significant changes. Nevertheless, the amount of P-Ser1177 decreased significantly to $\sim 30 \%-40 \%$ of the total eNOS, when cells were incubated with ox-VLDL (Figure 2(b)). Somewhat symmetrically, Thr495 (P-Thr495) is 40\% phosphorylated in the controls, reaching $\sim 60 \%$ phosphorylation 


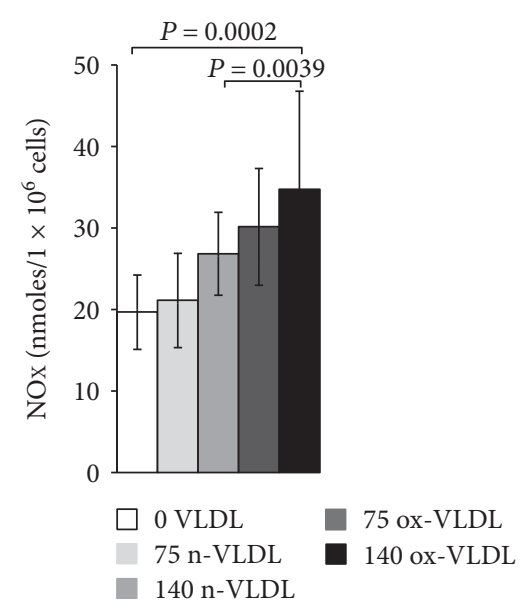

(a)

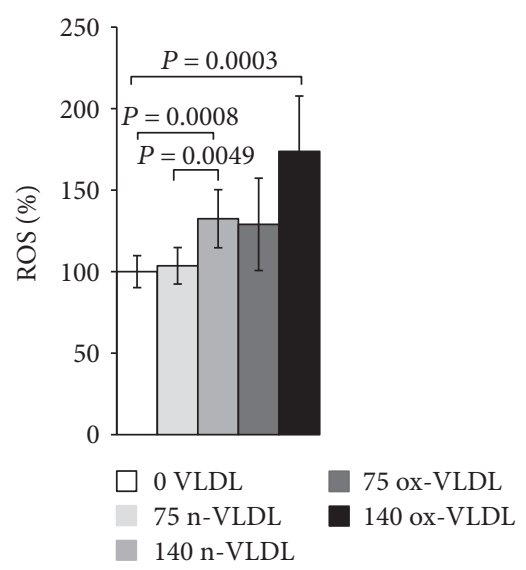

(b)

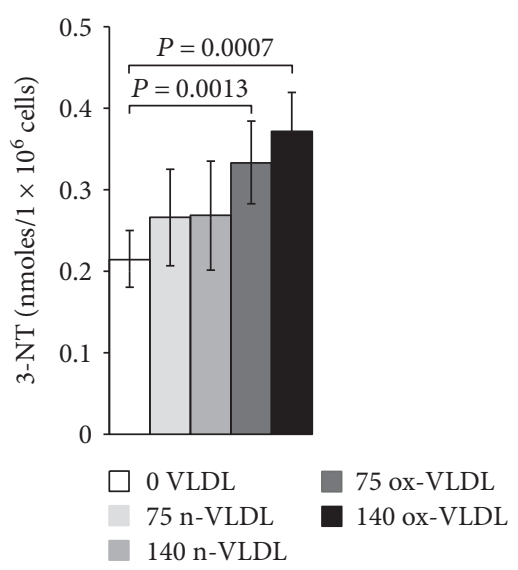

(c)

FIgURE 3: Oxidative and nitrosative stress driven in HUVEC by VLDL. Assays were carried out following $24 \mathrm{~h}$ incubation of HUVEC with n-VLDL or ox-VLDL (75 and $140 \mu \mathrm{g} / \mathrm{mL}$ ). (a) Nitrite-Nitrate (NOx) accumulation. NOx accumulation (24 h) was quantified in the cell supernatant downstream treatments by 2,3 -diaminonaphthalene (DAN) as described in the Materials and Methods section. Data \pm SD; $n$. of biological experiments $=5 . P$ values were considered statistically significant by ANOVA. (b) Reactive oxygen species (ROS) production. Intracellular ROS levels were measured in VLDL-treated and VLDL-untreated EC in the presence of 2,7-dichlorodihydrofluorescein diacetate (DCFDA) (see Materials and Methods). The DCFDA fluorescence was followed kinetically and the values taken at 30 min. Data are shown as percentage of ROS amount detected in untreated cells and normalised for protein content. Data are the means \pm SD; $n$. of biological experiments $=6 . P$ values were considered statistically significant by ANOVA. (c) 3-Nitrotyrosine (3-NT) determination. The 3-NT content was measured by nitrotyrosine competitive ELISA (see Materials and Methods) in VLDL-treated and VLDL-untreated cells (lysate). Data values are the means $\pm S D ; n$. of biological experiments $=5$. $P$ values were considered statistically significant by ANOVA.

upon incubation with n-VLDL, regardless to their concentration, in the limited range explored. At the highest ox-VLDL concentration, up to $\sim 90 \%$ threonin was phosphorylated (Figure 2(b)).

3.5. Nitrite/Nitrate, Reactive Oxygen Species, and 3-Nitrotyrosine. The accumulation of nitrite/nitrate (NOx), the production of ROS, and the concentration level of 3-NT were measured after $24 \mathrm{~h}$ incubation with VLDL. As shown in Figure 3(a), $\sim 20$ nmoles NOx was produced by $10^{6}$ control cells in $24 \mathrm{~h}$. Incubation with VLDL resulted in the increase of $\mathrm{NOx}$ production, as a function of VLDL concentration and oxidation state. $75 \mu \mathrm{g} / \mathrm{mL}$ and $140 \mu \mathrm{g} / \mathrm{mL}$ ox-VLDL resulted in the highest $\mathrm{NOx}$ increase, respectively, by 1.5 - and 2-fold with respect to controls. The production of ROS was also measured under similar conditions. As shown in Figure 3(b), the ROS level rises during the $24 \mathrm{~h}$ incubation, with increasing the concentration of VLDL, and more markedly if these are oxidised; the larger effect is observed at the highest ox-VLDL concentration. A comparable trend is observed when monitoring the level of 3-nitrotyrosine protein modification; this last finding, particularly, suggests a correlation between the persistence in the HUVEC environment of ox-VLDL and formation of the short-lived detrimental peroxynitrite (Figure 3(c)).

3.6. HUVEC Respiration. The $\mathrm{O}_{2}$ consumption of HUVEC following treatment with n-VLDL or ox-VLDL was measured oxigraphically. Measurements were carried out under different experimental conditions, such as using intact or digitonin-permeabilised cells in the presence or absence of specific mitochondrial substrates and respiratory chain inhibitors.

Typical traces are reported in Figure 4(a), where HUVEC untreated or incubated with n-VLDL or ox-VLDL, both $140 \mu \mathrm{g} \mathrm{mL}^{-1}$, were allowed to consume $\mathrm{O}_{2}$ in the presence and absence of selective activators or inhibitors of specific respiratory chain complexes $[49,50]$. The basal rates of $\mathrm{O}_{2}$ consumption have been measured and reported under all conditions (see Figure 4(b)). As shown in the figure, the incubation with $\mathrm{n}$-VLDL induces a $\sim 21 \%$ decrease of the $\mathrm{O}_{2}$ consumption, from $\sim 85$ pmoles $\mathrm{O}_{2} \mathrm{~s}^{-1}$ to $\sim 67$ pmoles $\mathrm{O}_{2} \mathrm{~s}^{-1}$. Moreover, the rate of respiration decreases, instead down to $\sim 59 \%$ of the initial value, if incubation is carried out with ox-VLDL.

The depression of $\mathrm{O}_{2}$ consumption appears slightly more evident in the presence of rotenone and succinate, inhibiting complex I and activating complex II, respectively (Figure 4(b)). The basal respiratory control ratio, RCR, was also affected by the VLDL incubation; it decreased from 1.74 to 1.50 and 1.40 , upon treatment with n-VLDL and ox-VLDL, respectively (see Figure 4(c)).

\section{Discussion}

The endothelium of vessels exposed to oxidative stress displays an altered availability of reactive oxygen and nitrogen species (RONS) that may result in disturbance of mitochondrial function and unbalancing of cell physiological signalling, aspects in which NO is known to play a crucial role [31, 51-54]. 


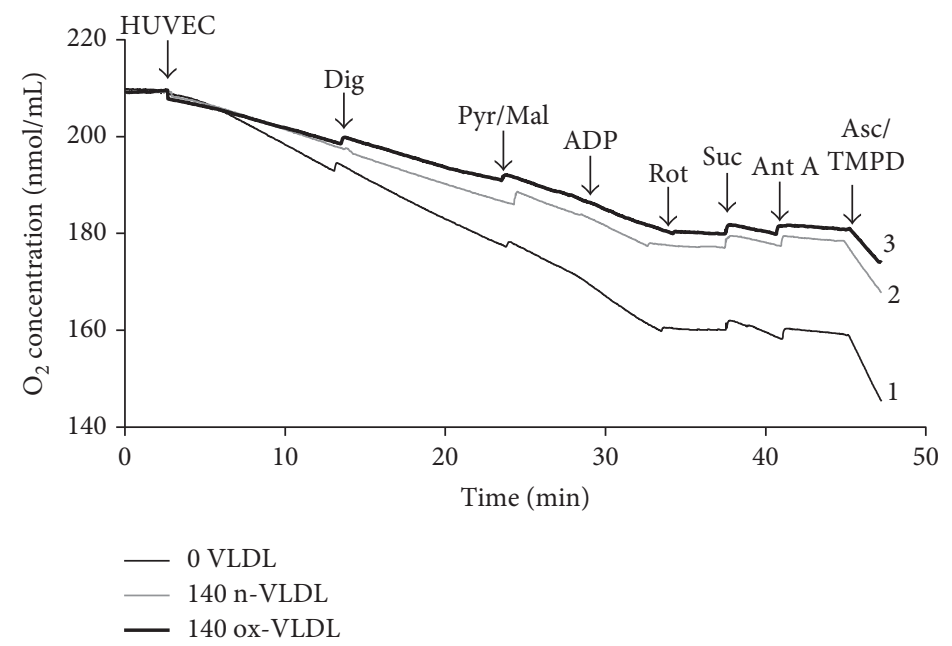

(a)

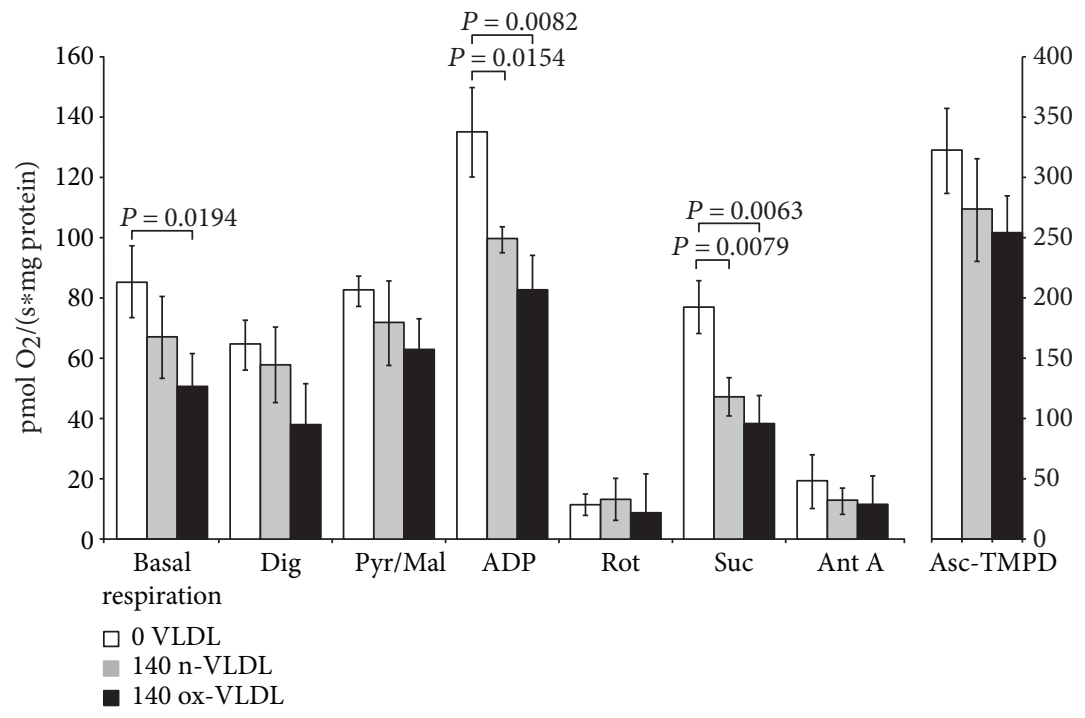

(b)

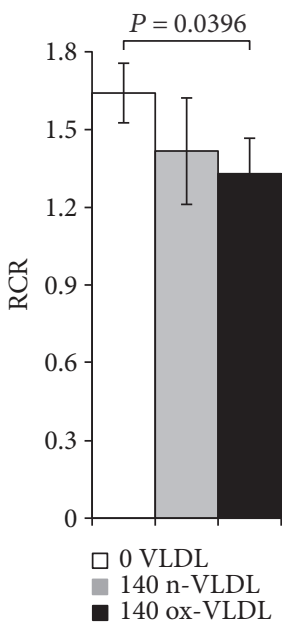

(c)

Figure 4: Evaluation of mitochondrial OXPHOS in response to VLDL treatment by $\mathrm{O}_{2}$ consumption measurements. (a) $\mathrm{O}_{2}$ consumption profiles. The oxygen consumption was monitored in $1 \times 10^{6}$ HUVEC after $24 \mathrm{~h}$ incubation under the conditions indicated; thin line: control cells (1); grey line: $140 \mu \mathrm{g} \mathrm{mL}^{-1} \mathrm{n}$-VLDL (2); bold line: $140 \mu \mathrm{g} \mathrm{mL} \mathrm{L}^{-1}$ ox-VLDL (3). Digitonin (Dig) was used to permeabilise cells. Substrates/inhibitors added along the trace: pyruvate and malate (Pyr/Mal); adenosine diphosphate (ADP); rotenone (Rot); succinate (Suc); antimycin A (Ant A); ascorbate and N,N,N', $\mathrm{N}^{\prime}$-tetrametil-p-fenilendiammina (Asc/TMPD). (b) $\mathrm{O}_{2}$ consumption rates. Respiration rate values measured in VLDL-treated HUVEC after each addition step (of substrate/inhibitor). Data values are the means \pm SD; $n$. of biological experiments $=3$. $P$ values were considered statistically significant by ANOVA. (c) Respiratory control ratio (RCR). The values of RCR were obtained as the ratio between the $\mathrm{O}_{2}$ consumption rate measured in the presence of saturating [ADP] (state 3) and in its absence (state 4). Data values are the means $\pm \mathrm{SD} ; n$. of biological experiments $=3$. $P$ values were considered statistically significant by ANOVA.

Bioavailability of $\mathrm{NO}$ at cell level depends on the activity of the NOS isoforms, so that physiological pathways ascribable to eNOS activity are featured by a limited (nM) amount of NO, whereas higher NO concentrations $(\mu \mathrm{M})$ resulting from the activation of iNOS are responsible for structural modifications such as membrane lipid peroxydation and protein nitrosation. These modifications are associated to the onset and maintenance of severe inflammatory states, including atherosclerosis $[34,55,56]$.

In this study, human umbilical vein endothelial cells (HUVEC) have been used as a model system to investigate the endothelium response to a persistent VLDL exposure.
The incubation time and the VLDL concentrations were chosen so to set a mild though clear dyslipidemic condition of pathophysiological relevance. Within the experimental limits of cells in culture mimicking endothelium microenvironment, cells were allowed to face for $24 \mathrm{~h}$ about twice as much the physiological blood concentration of VLDL $(140 \mu \mathrm{g} / \mathrm{mL}$ ), as prepared (native) or oxidized. The experimental design was such to investigate the role of VLDL in inducing nitro-oxidation of endothelium-like cells.

The analysis of NOS expression suggested the activation of a regulative antagonistic cross talk among the two NOS isoforms (eNOS and iNOS), so that the upregulation of the 


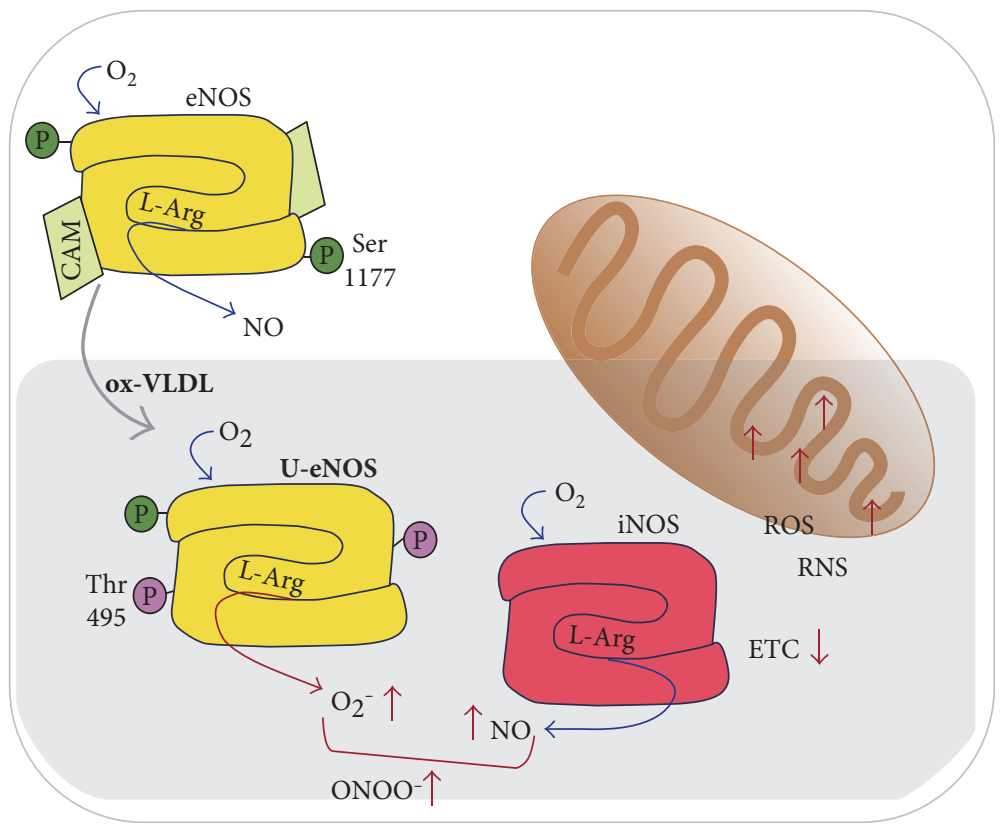

FIGURE 5: ox-VLDL-dependent EC dysfunction: schematic representation of the eNOS and iNOS involvement. The activity of eNOS (yellow) and iNOS (red) dimers are sketched. The coupled (native) eNOS is featured by the utilisation of substrates such as $\mathrm{L}-\mathrm{Arg}$ and $\mathrm{O}_{2}$ and production of $\mathrm{NO}$, in the presence of the cofactor calmodulin (CAM) and under condition of Ser1177 phosphorylation, promoting activity (white cell background). ox-VLDL triggers eNOS phosphorylation at residue Thr495, with dephosphorylation of Ser1177: under these conditions, the eNOS is uncoupled (U-eNOS) and results in the generation of $\mathrm{O}_{2}^{-\bullet}$. In parallel, high level of iNOS biosynthesis occurs, leading to increased ROS and RNS production and resulting in the down-modulation of mitochondrial function (gray background).

iNOS mRNA was accompanied, under comparable conditions, by a significant downregulation of the eNOS.

The iNOS activation is fully consistent with the increased production of NOx independently detected in the culture medium, suggesting a pathway of NO production which escapes the eNOS control. Furthermore, the increased production of ROS and 3-nitrotyrosine herein reported is consistent with the evidence of peroxynitrite formation compatible with a cogent inflammatory state of the cells [34].

The whole framework is also coherent with the upregulation of IL8 and VEGFA, genes involved in NO production and cell inflammatory response [57] and with the increased expression of NCF2 and NQO1 factors related to the NADPH oxidase function and biosynthesis $[58,59]$.

Consistently with the setting of an inflammatory state, the lowered eNOS synthesis induced by VLDL in HUVEC may imply an alteration of the physiological vasodilatory function relying on nanomolar NO fluxes. It is worth to notice that the eNOS is not only downregulated, according to both the mRNA and protein expression changes: based on the detected eNOS phosphorylation pattern (by targeting phospho-Ser1177 and phospho-Thr495), the enzyme appears also largely uncoupled hence supporting the production of superoxide ion [60-62].

The relevance of the proposed involvement of VLDL in the biosynthetic and functional regulation of eNOS was supported by changes found, over the same time scale, on the regulation of genes involved to NOS stability and function $[63,64]$. The decreased expression of DDAH2, scavenger of an eNOS inhibitor (ADMA) [65], as well as the upregulation of ARG2, responsible for the depletion of arginine, were all elements pointing to the impairment of the physiological production of NO.

Interestingly, and somehow discordant with the above findings, some differences in the expression of other genes from the same array, as the modest upregulation of HSP90, involved in maintaining the dimeric structure of eNOS [66] and of GLA, responsible for degradation of the eNOS uncoupler Gb3 [67], seemed to point out the activation of compensatory pathways possibly aimed to the preservation of the eNOS function. Furthermore, the upregulation of the enzyme GCH1, involved in $\mathrm{BH} 4$ biosynthesis, combined to the downregulation of its feedback regulator GCHFR, suggests that under conditions in which BH4 oxidation is feasible, such as under oxidising conditions, signals enhancing $\mathrm{BH} 4$ bioavailability may be activated by endothelial cells, aimed at preventing or possibly reverting eNOS uncoupling $[38,68]$.

It is interesting to underline that upon VLDL treatment, the observed increase in ROS concentration follows a trend fully consistent with the progress of eNOS uncoupling, detected by Western blot. A peak in ROS concentration was found after $140 \mu \mathrm{g} / \mathrm{mL}$ ox-VLDL administration, a condition matching that responsible for the ultimate eNOS uncoupling (lowest phospho-Ser1177, highest phospho-Thr495).

It may be also interesting to point out that the increased production of superoxide goes along with a mild upregulation of SOD1 and SOD2 mRNAs (Figure $1(\mathrm{~d})$ ), thus suggesting a cell attempt to tempering ROS rise.

Beside NO, ROS are also involved in the maintenance of physiological vascular homeostasis, through a tight control exerted by healthy endothelial cells. 
The setting of prooxidative conditions was shown to result in increased ROS production, associated with the activation of signals promoting oxidative damage [22, 69].

Hence, the VLDL-induced cell redox changes are characterised by the concurrent synthesis of NO by the iNOS and of $\mathrm{O}_{2}^{-\bullet}$ by the uncoupled eNOS. These two evidences are fully compatible with the observed production of the highly reactive species peroxynitrite, probed by the increased tyrosine nitration.

Ox-VLDL treatment appears to be the condition necessary and sufficient to determine peroxynitrite formation, as the increase of 3-NT was found significant already at $75 \mu \mathrm{g} / \mathrm{mL}$, compared to control cells; this may suggest a specific interaction of ox-VLDL with the scavenger receptors. As already reported for ox-LDL, this class of cell surface receptors may specifically recognise oxidised lipoproteins, thus activating typical inflammatory cell response $[70,71]$.

The whole picture appears consistent with the onset and/or maintenance of a nitrosative stress in endothelial cells undergoing VLDL treatments; within this frame, the determination of the functional state of mitochondria is relevant to define the level of cell dysfunction.

VLDL induced a functional decrease (mild if native, more evident if oxidised) of mitochondrial respiration. The mitochondrial respiratory control ratio (RCR) also followed a similar trend. The respiratory chain activity, evaluated at the level of the specific mitochondrial complexes, showed a decrease of the electron transfer efficiency ( 20\%), detected almost uniformly along the chain, apparently just slightly more at the level of complex II ( $50 \%$ inhibition by ox-VLDL).

As the observed impairment on mitochondrial respiration may not be unequivocally attributed to a specific respiratory complex, it appears feasible to envisage that the oxi/ nitrosative stress induced by VLDL may determine relevant modification of mitochondrial proteins, such as protein nitrosation, causing an interference with the electron transfer process. The persistency of these conditions would bring to supercomplex disaggregation and alteration of the mitochondrial proteolipid arrangement.

\section{Conclusions}

From these experiments, we can propose that $24 \mathrm{~h}$ incubation of HUVEC with native and oxidised VLDL triggers a signalling leading to iNOS activation and eNOS uncoupling.

These events, resulting in an unbalance of $\mathrm{NO}$ and ROS metabolism, are more clearly produced by excess of ox-VLDL leading to production of harmful proxynitrite and triggering a cell inflammatory state. Consistently, cells display a lower mitochondrial $\mathrm{O}_{2}$ consumption and RCR (Figure 5).

It is tempting to speculate on the biomedical relevance of these results: an altered lipid metabolism arising from both a genetic or epigenetic background could represent a condition in which an inadequate lifestyle (smoking abuse, highly processed food consumption, and pollution) provides an additional detrimental contribution, perceived by the endothelium of vessel as a prooxidant insult.
According to our results, the early dysfunction of the eNOS associated to iNOS activation driven by VLDL can be relevant to set conditions compatible with the development of atherosclerosis.

\section{Abbreviations}

ADMA: Asymmetric dimethylarginine

ADP: $\quad$ Adenosine diphosphate

ALOX12: Arachidonate 12-lipoxygenase, 12S type

ARG2: $\quad$ Arginase, type II

BSA: $\quad$ Bovine serum albumin

cDNA: Complementary DNA

DDAH2: Dimethylarginine dimethylaminohydrolase 2

EC: $\quad$ Endothelial cells

eNOS: $\quad$ Endothelial nitric oxide synthase

EDTA: Ethylenediaminetetraacetic acid

Gb3: Globotriaosylceramide

GCH1: $\quad$ GTP cyclohydrolase 1

GCHFR: GTP cyclohydrolase I feedback regulator

GLA: Galactosidase alpha

HSP90AB1: Heat shock protein $90 \mathrm{kDa} \alpha$, class B member 1

HUVEC: Human umbilical vein endothelial cells

IL8: $\quad$ Interleukin 8

iNOS: $\quad$ Inducible NOS

LDL: Low-density lipoproteins

NCF2: $\quad$ Neutrophil cytosolic factor 2

NO: $\quad$ Nitric oxide

nNOS: Neuronal NOS

NOx: $\quad$ Nitrites and nitrates

NQO1: $\quad \mathrm{NAD}(\mathrm{P}) \mathrm{H}$ dehydrogenase, quinone 1

n-VLDL: Native VLDL

ox-VLDL: Oxidised VLDL

PBS: $\quad$ Phosphate-buffered saline

PCR: $\quad$ Polymerase chain reaction

P-Ser1177: Phosphorylated serine 1177

P-Thr495: Phosphorylated threonine 495

RNS: $\quad$ Reactive nitrogen species

ROS: $\quad$ Reactive oxygen species

RONS: Reactive oxygen and nitrogen species

Thr: Threonine

RCR: Respiratory control ratio

Ser: Serine

SOD1: $\quad$ Superoxide dismutase 1

SOD2: $\quad$ Superoxide dismutase 2

VEGFA: Vascular endothelial growth factor A

VLDL: Very-low-density lipoproteins

U-eNOS: Uncoupled eNOS

3-NT: 3-Nitrotyrosine.

\section{Conflicts of Interest}

The authors declare that there is no conflict of interests regarding the publication of this paper.

\section{Authors' Contributions}

Maria Chiara Magnifico and Roxana Elena Oberkersch have contributed equally to this work. 


\section{Acknowledgments}

This work was supported by the Ministero dell'Istruzione, dell'Università e della Ricerca (MIUR) of Italy (PRIN20107Z8XBW 005) to Paolo Sarti and Regione Lazio of Italy (FILAS-RU-2014-1020) to Paolo Sarti. The Erasmus Mundus Programme Action 2 Arcoiris Partnership (UID ARCO1100237) and ERASMUS + Programme (KA103) are acknowledged for supporting Roxana Elena Oberkersch and Yasmine Grooten. The authors gratefully acknowledged the staff from the "Immunohematology and Transfusion Medicine" UOC of Policlinico Umberto I and particularly Dr. Rosato V. and Dr. Malanga G. for the selection of blood samples from healthy volunteers used in this study. The authors are grateful to Dr. Alessio Paone for supporting them in the statistical analysis of the results.

\section{References}

[1] Y. Nakashima, T. N. Wight, and K. Sueishi, "Early atherosclerosis in humans: role of diffuse intimal thickening and extracellular matrix proteoglycans," Cardiovascular Research, vol. 79, no. 1, pp. 14-23, 2008.

[2] I. Tabas, G. Garcia-Cardena, and G. K. Owens, "Recent insights into the cellular biology of atherosclerosis," The Journal of Cell Biology, vol. 209, no. 1, pp. 13-22, 2015.

[3] H. A. Jensen and J. L. Mehta, "Endothelial cell dysfunction as a novel therapeutic target in atherosclerosis," Expert Review of Cardiovascular Therapy, vol. 14, no. 9, pp. 1021-1033, 2016.

[4] M. S. Rahman, A. J. Murphy, and K. J. Woollard, "Effects of dyslipidaemia on monocyte production and function in cardiovascular disease," Nature Reviews Cardiology, vol. 14, no. 7, pp. 387-400, 2017.

[5] A. Negre-Salvayre, N. Auge, C. Camare, T. Bacchetti, G. Ferretti, and R. Salvayre, "Dual signaling evoked by oxidized LDLs in vascular cells," Free Radical Biology \& Medicine, vol. 106, pp. 118-133, 2017.

[6] V. Lubrano and S. Balzan, "LOX-1 and ROS, inseparable factors in the process of endothelial damage," Free Radical Research, vol. 48, no. 8, pp. 841-848, 2014.

[7] V. N. Sukhorukov, V. P. Karagodin, and A. N. Orekhov, "Atherogenic modification of low-density lipoproteins," Biomeditsinskaya Khimiya, vol. 62, no. 4, pp. 391-402, 2016.

[8] K. E. Petersen, J. Lykkesfeldt, K. Raun, and G. Rakipovski, "Brief communication: plasma lipid oxidation predicts atherosclerotic status better than cholesterol in diabetic apolipoprotein E deficient mice," Experimental Biology and Medicine, vol. 242, no. 1, pp. 88-91, 2017.

[9] G. Ferretti, T. Bacchetti, T. P. Johnston, M. Banach, M. Pirro, and A. Sahebkar, "Lipoprotein(a): a missing culprit in the management of athero-thrombosis?"” Journal of Cellular Physiology, 2017.

[10] S. Takahashi, J. Sakai, T. Fujino et al., "The very low-density lipoprotein (VLDL) receptor: characterization and functions as a peripheral lipoprotein receptor," Journal of Atherosclerosis and Thrombosis, vol. 11, no. 4, pp. 200-208, 2004.

[11] P. Xie, Y. Duan, X. Guo, L. Hu, and M. Yu, "SalA attenuates hypoxia-induced endothelial endoplasmic reticulum stress and apoptosis via down-regulation of VLDL receptor expression," Cellular Physiology and Biochemistry, vol. 35, no. 1, pp. 17-28, 2015.
[12] G. D. Norata, A. Pirillo, E. Callegari, A. Hamsten, A. L. Catapano, and P. Eriksson, "Gene expression and intracellular pathways involved in endothelial dysfunction induced by VLDL and oxidised VLDL," Cardiovascular Research, vol. 59, no. 1, pp. 169-180, 2003.

[13] M. C. Jong, W. L. Hendriks, L. C. van Vark, V. E. Dahlmans, J. E. Groener, and L. M. Havekes, "Oxidized VLDL induces less triglyceride accumulation in J774 macrophages than native VLDL due to an impaired extracellular lipolysis," Arteriosclerosis, Thrombosis, and Vascular Biology, vol. 20, no. 1, pp. 144-151, 2000.

[14] L. Wang, R. Gill, T. L. Pedersen, L. J. Higgins, J. W. Newman, and J. C. Rutledge, "Triglyceride-rich lipoprotein lipolysis releases neutral and oxidized FFAs that induce endothelial cell inflammation," Journal of Lipid Research, vol. 50, no. 2, pp. 204-213, 2009.

[15] T. Kita, N. Kume, M. Minami et al., "Role of oxidized LDL in atherosclerosis," Annals of the New York Academy of Sciences, vol. 947, pp. 199-205, 2001.

[16] V. Mollace, M. Gliozzi, V. Musolino et al., "Oxidized LDL attenuates protective autophagy and induces apoptotic cell death of endothelial cells: role of oxidative stress and LOX-1 receptor expression," International Journal of Cardiology, vol. 184, pp. 152-158, 2015.

[17] D. P. Hajjar and A. M. Gotto Jr., "Biological relevance of inflammation and oxidative stress in the pathogenesis of arterial diseases," The American Journal of Pathology, vol. 182, no. 5, pp. 1474-1481, 2013.

[18] S. H. Chan, C. H. Hung, J. Y. Shih et al., "Baicalein is an available anti-atherosclerotic compound through modulation of nitric oxide-related mechanism under oxLDL exposure," Oncotarget, vol. 7, no. 28, pp. 42881-42891, 2016.

[19] A. Almeida and J. P. Bolanos, "A transient inhibition of mitochondrial ATP synthesis by nitric oxide synthase activation triggered apoptosis in primary cortical neurons," Journal of Neurochemistry, vol. 77, no. 2, pp. 676-690, 2001.

[20] P. Dromparis and E. D. Michelakis, "Mitochondria in vascular health and disease," Annual Review of Physiology, vol. 75, pp. 95-126, 2013.

[21] X. Tang, Y. X. Luo, H. Z. Chen, and D. P. Liu, "Mitochondria, endothelial cell function, and vascular diseases," Frontiers in Physiology, vol. 5, p. 175, 2014.

[22] N. R. Madamanchi and M. S. Runge, "Mitochondrial dysfunction in atherosclerosis," Circulation Research, vol. 100, no. 4, pp. 460-473, 2007.

[23] I. A. Sobenin, M. A. Sazonova, A. Y. Postnov, Y. V. Bobryshev, and A. N. Orekhov, "Changes of mitochondria in atherosclerosis: possible determinant in the pathogenesis of the disease," Atherosclerosis, vol. 227, no. 2, pp. 283-288, 2013.

[24] J. D. Erusalimsky and S. Moncada, "Nitric oxide and mitochondrial signaling: from physiology to pathophysiology," Arteriosclerosis, Thrombosis, and Vascular Biology, vol. 27, no. 12, pp. 2524-2531, 2007.

[25] R. P. Patel, D. Moellering, J. Murphy-Ullrich, H. Jo, J. S. Beckman, and V. M. Darley-Usmar, "Cell signaling by reactive nitrogen and oxygen species in atherosclerosis," Free Radical Biology \& Medicine, vol. 28, no. 12, pp. 1780-1794, 2000.

[26] A. Giuffre, V. B. Borisov, M. Arese, P. Sarti, and E. Forte, "Cytochrome bd oxidase and bacterial tolerance to oxidative and nitrosative stress," Biochimica et Biophysica Acta (BBA) Bioenergetics, vol. 1837, no. 7, pp. 1178-1187, 2014. 
[27] J. B. Vicente, F. Malagrino, M. Arese, E. Forte, P. Sarti, and A. Giuffrè, "Bioenergetic relevance of hydrogen sulfide and the interplay between gasotransmitters at human cystathionine $\beta$-synthase," Biochimica et Biophysica Acta (BBA) - Bioenergetics, vol. 1857, no. 8, pp. 1127-1138, 2016.

[28] N. Zhang, Y. Diao, R. Hua et al., "Nitric oxide-mediated pathways and its role in the degenerative diseases," Frontiers in Bioscience (Landmark Edition), vol. 22, pp. 824-834, 2017.

[29] C. Bogdan, "Nitric oxide synthase in innate and adaptive immunity: an update," Trends in Immunology, vol. 36, no. 3, pp. 161-178, 2015.

[30] A. Galkin, A. Y. Abramov, N. Frakich, M. R. Duchen, and S. Moncada, "Lack of oxygen deactivates mitochondrial complex I: implications for ischemic injury?," The Journal of Biological Chemistry, vol. 284, no. 52, pp. 36055-36061, 2009.

[31] P. Sarti, E. Forte, A. Giuffre, D. Mastronicola, M. C. Magnifico, and M. Arese, "The chemical interplay between nitric oxide and mitochondrial cytochrome $c$ oxidase: reactions, effectors and pathophysiology," International Journal of Cell Biology, vol. 2012, Article ID 571067, 11 pages, 2012.

[32] P. Sarti, E. Lendaro, R. Ippoliti, A. Bellelli, P. A. Benedetti, and M. Brunori, "Modulation of mitochondrial respiration by nitric oxide: investigation by single cell fluorescence microscopy," The FASEB Journal, vol. 13, no. 1, pp. 191-197, 1999.

[33] S. Moncada and E. A. Higgs, "The discovery of nitric oxide and its role in vascular biology," British Journal of Pharmacology, vol. 147, Supplement 1, pp. S193-S201, 2006.

[34] P. Pacher, J. S. Beckman, and L. Liaudet, "Nitric oxide and peroxynitrite in health and disease," Physiological Reviews, vol. 87, no. 1, pp. 315-424, 2007.

[35] A. Chatterjee, S. M. Black, and J. D. Catravas, "Endothelial nitric oxide (NO) and its pathophysiologic regulation," Vascular Pharmacology, vol. 49, no. 4-6, pp. 134-140, 2008.

[36] S. Karbach, P. Wenzel, A. Waisman, T. Munzel, and A. Daiber, "eNOS uncoupling in cardiovascular diseases-the role of oxidative stress and inflammation," Current Pharmaceutical Design, vol. 20, no. 22, pp. 3579-3594, 2014.

[37] U. Forstermann and W. C. Sessa, "Nitric oxide synthases: regulation and function," European Heart Journal, vol. 33, no. 7, pp. 829-837, 2012, 837a-837d.

[38] H. Li and U. Forstermann, "Uncoupling of endothelial NO synthase in atherosclerosis and vascular disease," Current Opinion in Pharmacology, vol. 13, no. 2, pp. 161-167, 2013.

[39] P. Sarti, M. Arese, E. Forte, A. Giuffrè, and D. Mastronicola, "Mitochondria and nitric oxide: chemistry and pathophysiology," Advances in Experimental Medicine and Biology, vol. 942, pp. 75-92, 2012.

[40] P. A. Srere, "Citrate synthase," Methods in Enzymology, vol. 13, pp. 3-11, 1969.

[41] T. G. Redgrave, D. C. Roberts, and C. E. West, "Separation of plasma lipoproteins by density-gradient ultracentrifugation," Analytical Biochemistry, vol. 65, no. 1-2, pp. 42-49, 1975.

[42] A. Cwiklinska, B. Kortas-Stempak, A. Gliwinska, A. Pacanis, A. Kuchta, and M. Wróblewska, "Interaction between VLDL and phosphatidylcholine liposomes generates new $\gamma$-LpE-like particles," Lipids, vol. 49, no. 2, pp. 143-153, 2014.

[43] M. Guha, C. England, H. Herscovitz, and O. Gursky, "Thermal transitions in human very-low-density lipoprotein: fusion, rupture, and dissociation of HDL-like particles," Biochemistry, vol. 46, no. 20, pp. 6043-6049, 2007.
[44] M. Guha and O. Gursky, "Effects of oxidation on structural stability and remodeling of human very low density lipoprotein," Biochemistry, vol. 49, no. 44, pp. 9584-9593, 2010.

[45] U. P. Steinbrecher, S. Parthasarathy, D. S. Leake, J. L. Witztum, and D. Steinberg, "Modification of low density lipoprotein by endothelial cells involves lipid peroxidation and degradation of low density lipoprotein phospholipids," Proceedings of the National Academy of Sciences of the United States of America, vol. 81, no. 12, pp. 3883-3887, 1984.

[46] K. Yagi, "A simple fluorometric assay for lipoperoxide in blood plasma," Biochemical Medicine, vol. 15, no. 2, pp. 212-216, 1976.

[47] S. Robin, M. Arese, E. Forte, P. Sarti, A. Giuffrè, and T. Soulimane, "A sulfite respiration pathway from Thermus thermophilus and the key role of newly identified cytochrome $c_{550}$," Journal of Bacteriology, vol. 193, no. 15, pp. 3988-3997, 2011.

[48] A. Masci, D. Mastronicola, M. Arese et al., "Control of cell respiration by nitric oxide in Ataxia Telangiectasia lymphoblastoid cells," Biochimica et Biophysica Acta (BBA) - Bioenergetics, vol. 1777, no. 1, pp. 66-73, 2008.

[49] E. Gnaiger, A. V. Kuznetsov, B. Lassnig et al., "High-resolution respirometry-optimum permeabilization of the cell membrane by digitonin," BioThermoKinetics in the Post Genomic era, C. Larsson, I. Pahlman and L. Gustafsson, Eds., p. 7, 1998.

[50] A. V. Kuznetsov, V. Veksler, F. N. Gellerich, V. Saks, R. Margreiter, and W. S. Kunz, "Analysis of mitochondrial function in situ in permeabilized muscle fibers, tissues and cells," Nature Protocols, vol. 3, no. 6, pp. 965-976, 2008.

[51] J. Gutierrez, S. W. Ballinger, V. M. Darley-Usmar, and A. Landar, "Free radicals, mitochondria, and oxidized lipids: the emerging role in signal transduction in vascular cells," Circulation Research, vol. 99, no. 9, pp. 924-932, 2006.

[52] M. A. Kluge, J. L. Fetterman, and J. A. Vita, "Mitochondria and endothelial function," Circulation Research, vol. 112, no. 8, pp. 1171-1188, 2013.

[53] G. C. Brown, "Nitric oxide regulates mitochondrial respiration and cell functions by inhibiting cytochrome oxidase," FEBS Letters, vol. 369, no. 2-3, pp. 136-139, 1995.

[54] U. Forstermann, "Nitric oxide and oxidative stress in vascular disease," Pflügers Archiv, vol. 459, no. 6, pp. 923-939, 2010.

[55] M. Falabella, E. Forte, M. C. Magnifico et al., "Evidence for detrimental cross interactions between reactive oxygen and nitrogen species in Leber's hereditary optic neuropathy cells," Oxidative Medicine and Cellular Longevity, vol. 2016, Article ID 3187560, 9 pages, 2016.

[56] M. Arese, M. C. Magnifico, D. Mastronicola et al., "Nanomolar melatonin enhances nNOS expression and controls HaCaTcells bioenergetics," IUBMB Life, vol. 64, no. 3, pp. 251-258, 2012.

[57] Y. I. Wang, J. Schulze, N. Raymond et al., "Endothelial inflammation correlates with subject triglycerides and waist size after a high-fat meal," American Journal of Physiology Heart and Circulatory Physiology, vol. 300, no. 3, pp. H784-H791, 2011.

[58] K. Bedard and K. H. Krause, "The NOX family of ROS-generating NADPH oxidases: physiology and pathophysiology," Physiological Reviews, vol. 87, no. 1, pp. 245-313, 2007.

[59] K. Itoh, P. Ye, T. Matsumiya, K. Tanji, and T. Ozaki, "Emerging functional cross-talk between the Keap1-Nrf2 system and mitochondria," Journal of Clinical Biochemistry and Nutrition, vol. 56, no. 2, pp. 91-97, 2015. 
[60] B. J. Michell, Z. Chen, T. Tiganis et al., "Coordinated control of endothelial nitric-oxide synthase phosphorylation by protein kinase $\mathrm{C}$ and the cAMP-dependent protein kinase," The Journal of Biological Chemistry, vol. 276, no. 21, pp. 17625-17628, 2001.

[61] L. A. Biwer, E. P. Taddeo, B. M. Kenwood, K. L. Hoehn, A. C. Straub, and B. E. Isakson, "Two functionally distinct pools of eNOS in endothelium are facilitated by myoendothelial junction lipid composition," Biochimica et Biophysica Acta (BBA) - Molecular and Cell Biology of Lipids, vol. 1861, no. 7, pp. 671-679, 2016.

[62] F. Chen, S. Kumar, Y. Yu et al., "PKC-dependent phosphorylation of eNOS at T495 regulates eNOS coupling and endothelial barrier function in response to $\mathrm{G}^{+}$-toxins," PLoS One, vol. 9, no. 7, article e99823, 2014.

[63] Q. Li, J. Y. Youn, and H. Cai, "Mechanisms and consequences of endothelial nitric oxide synthase dysfunction in hypertension," Journal of Hypertension, vol. 33, no. 6, pp. 1128-1136, 2015.

[64] G. H. Oliveira-Paula, R. Lacchini, and J. E. Tanus-Santos, "Endothelial nitric oxide synthase: from biochemistry and gene structure to clinical implications of NOS3 polymorphisms," Gene, vol. 575, no. 2, Part 3, pp. 584-599, 2015.

[65] S. Lambden, P. Kelly, B. Ahmetaj-Shala et al., "Dimethylarginine dimethylaminohydrolase 2 regulates nitric oxide synthesis and hemodynamics and determines outcome in polymicrobial sepsis," Arteriosclerosis, Thrombosis, and Vascular Biology, vol. 35, no. 6, pp. 1382-1392, 2015.

[66] W. Chen, H. Xiao, A. N. Rizzo, W. Zhang, Y. Mai, and M. Ye, "Endothelial nitric oxide synthase dimerization is regulated by heat shock protein 90 rather than by phosphorylation," PLoS One, vol. 9, no. 8, article e105479, 2013.

[67] J. L. Park, S. E. Whitesall, L. G. D'Alecy, L. Shu, and J. A. Shayman, "Vascular dysfunction in the alpha-galactosidase A-knockout mouse is an endothelial cell-, plasma membranebased defect," Clinical and Experimental Pharmacology \& Physiology, vol. 35, no. 10, pp. 1156-1163, 2008.

[68] K. Zschiebsch, C. Fischer, G. Pickert et al., "Tetrahydrobiopterin attenuates DSS-evoked colitis in mice by rebalancing redox and lipid signalling," Journal of Crohn's \& Colitis, vol. 10, no. 8, pp. 965-978, 2016.

[69] M. E. Widlansky and D. D. Gutterman, "Regulation of endothelial function by mitochondrial reactive oxygen species," Antioxidants \& Redox Signaling, vol. 15, no. 6, pp. 1517-1530, 2011.

[70] I. A. Zani, S. L. Stephen, N. A. Mughal et al., "Scavenger receptor structure and function in health and disease," Cell, vol. 4, no. 2, pp. 178-201, 2015.

[71] A. Pirillo, G. D. Norata, and A. L. Catapano, "LOX-1, OxLDL, and atherosclerosis," Mediators of Inflammation, vol. 2013, Article ID 152786, 12 pages, 2013. 


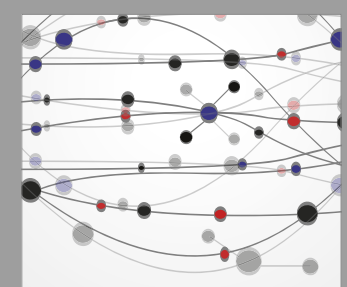

The Scientific World Journal
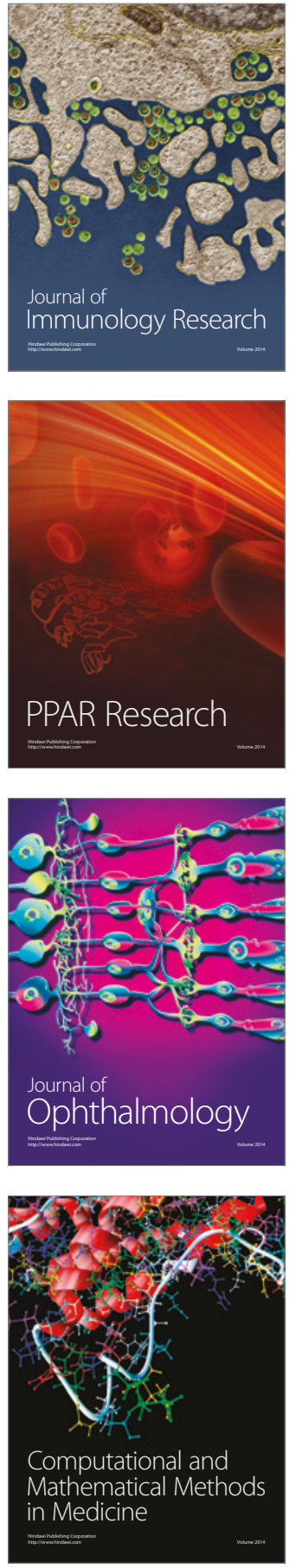

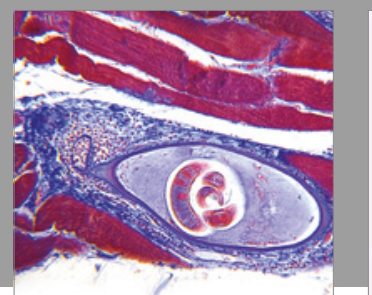

Gastroenterology Research and Practice
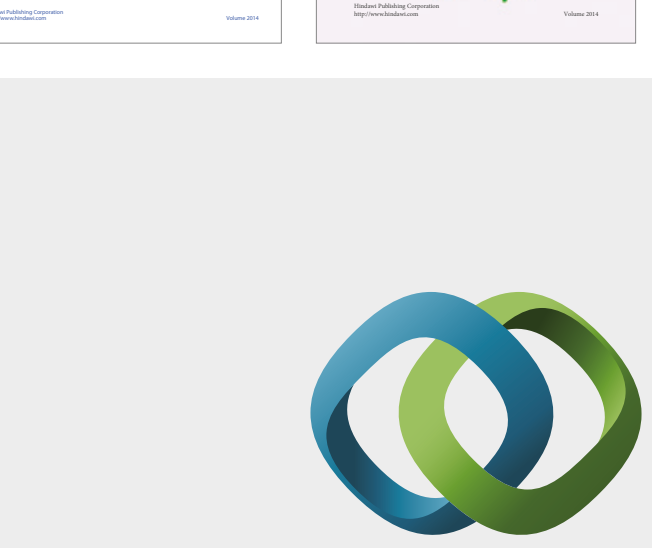

\section{Hindawi}

Submit your manuscripts at

https://www.hindawi.com
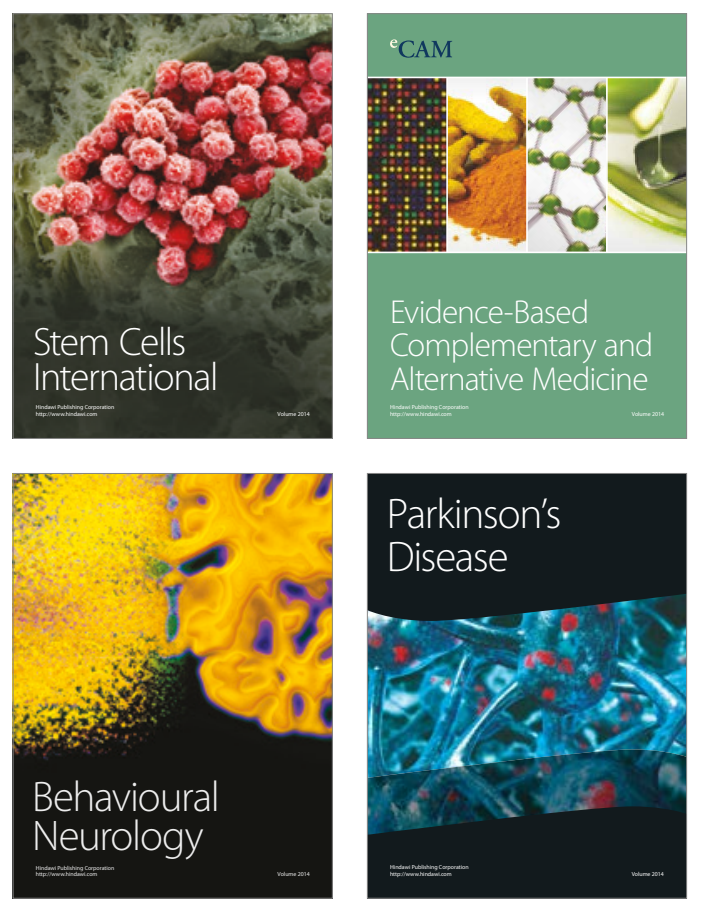
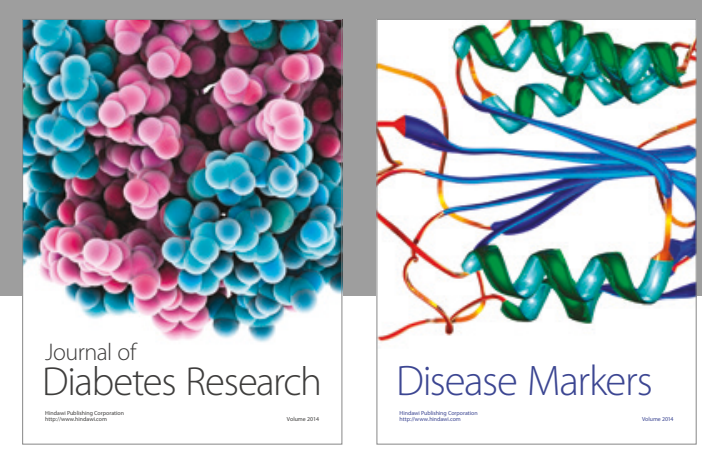

Disease Markers
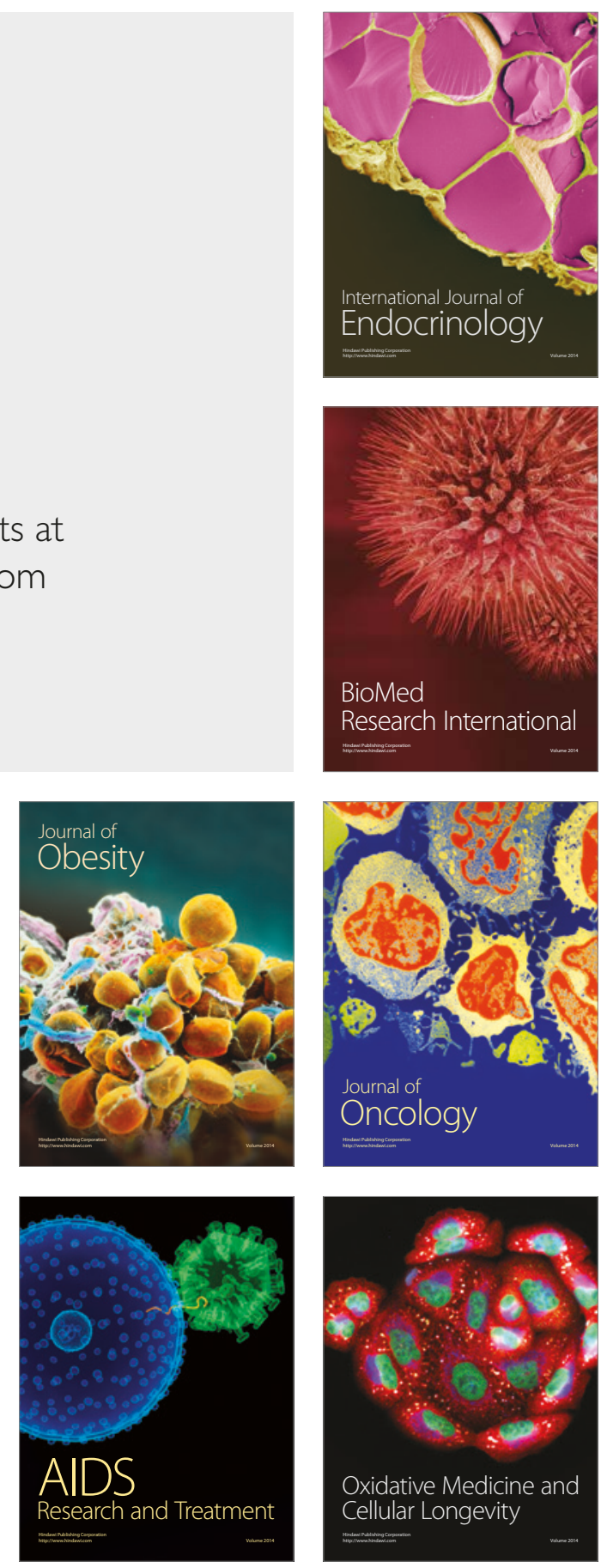